\title{
DGGE detection and screening of lignocellulolytic bacteria from the termite gut of Coptotermes formosanus
}

\author{
Gincy Marina Mathew ${ }^{\mathrm{a}}$, Shu-Juan Lin ${ }^{\mathrm{a}}$, Jui-Jen Chang ${ }^{\mathrm{b}}$ and Chieh-Chen Huang ${ }^{\mathrm{a}}$ \\ ${ }^{a}$ Department of Life Sciences, National Chung Hsing University, 40227 Taiwan. \\ ${ }^{b}$ Genomic Research Center, Academia Sinica, Taipei 115, Taiwan. \\ E-mail: cchuang@dragon.nchu.edu.tw
}

Received 25 July 2011; received in revised form 12 August 2011; accepted 16 August 2011

\begin{abstract}
Aims: Termites thrive in terrestrial ecosystems and play an important role in the bio-recycling of lignocellulose. The objective of this study is to isolate and detect bacteria from the termite gut of Coptotermes formosanus and to screen their various enzyme activities by qualitative methods. In addition, this study was aimed to isolate lignin and furfural tolerant strains for various industrial bioprocesses.

Methodology and Results: In this study, 50 worker termites of Coptotermes formosanus were collected from dead trees, from a forest in Taichung, Taiwan in June 2008 and the composition of the microbial flora from the termite guts was analyzed by DGGE analysis. The results proved that anaerobic and facultatively anaerobic bacteria consisting of Acinetobacter, Bacteroides thetaiotaomicron, Escherichia coli, and Caulobacter readily existed in the guts of termites. Although the majority of these gut symbionts have not yet been cultivated or identified, some related bacteria were isolated. Two isolates 1-8 and 2-2 of Genus Bacillus, exhibited endocellulase, protease, lipase, amylase, peroxidase and lignin peroxidase activity. Under aerobic conditions, the growth density of isolate 1-8 cultured in $1000 \mathrm{ppm}$ lignin containing MSM medium was two-folds higher than cultured in MSM medium without lignin. Furthermore, the isolate 1-8 was tolerant to $20 \mathrm{mM}$ furfural supplemented in the MSM medium. HPLC analysis confirmed Bacillus isolate 1-8 could degrade up to $15 \mathrm{mM}$ furfural.

Conclusion, significance and impact of study: Hind gut bacteria from $C$. formosanus were detected by culture independent DGGE method. Also, Bacillus isolates 1-8 and 2-2 obtained by culture dependent methods could withstand higher concentration of furfural and as well as lignin. These isolates may be co-cultured with ethanologenic bacteria and be used as an industrial biocatalyst for biofuel production.
\end{abstract}

Keywords: lignocellulose, termite gut, Coptotermes formosanus, Bacillus

\section{INTRODUCTION}

Lignin is a complex chemical compound, most commonly derived from wood and cross-linked racemic macromolecule with molecular masses in excess of 10,000 units. It is relatively hydrophobic and aromatic in nature and present in plants and some algae, and is one of the most abundant organic polymers on Earth, exceeded only by cellulose (Pérez et al., 2002). Lignin fills the spaces in the cell wall between cellulose, hemicellulose, and pectin components for covalently linking to hemicellulose and polysaccharides, forming the lignocellulosic substrates (Chabannes et al., 2001). These substrates are degraded by ligninolytic and cellulolytic enzymes which are secreted by certain fungi and bacteria. The lignin degrading enzymes present in these fungi and bacteria are manganese peroxidase, lignin peroxidase and laccase (Harazono et al., 2003) whereas the cellulose degrading enzymes are endo-1,4-beta-D-glucanase (endoglucanase), exo-1,4-beta-D-glucanase (exoglucanase) and beta-glucosidase (Bhat and Bhat, 1997).
In the nature, termites (Isoptera) are important for the degradation and utilization of plant matter which is constituted of cellulose, hemicellulose, lignin, and aromatic compounds. Based on their food habits, the termites are classified into three groups: wood-feeders, fungus-growers and soil-feeders respectively. As a result of their varied food habits, they have developed different pathways for the degradation of their food substrates. Termites can digest these complex organic matters through their gut system comprising of a foregut, midgut, mixed segment, first proctodeal segment, enteric valve and paunch, colon and rectum (Tokuda et al., 2000; Kudo, 2009). Certain termites have a specialized hindgut flora, consisting of symbiotic bacteria and protozoa that enable them to degrade organic matter. In "higher termites", these protozoa are absent and are known to possess prokaryotes not only in the hindgut but also in the mixed segment (Tokuda et al., 2000). In "lower termites", intestinal bacteria contribute to creating suitable conditions for symbiotic protozoa (flagellates) and metabolites from the microorganisms are considered to be absorbed across the hindgut wall in the hindgut (the 
paunch) (Harazono et al., 2003). The protozoa survive on a diet of carbohydrates consisting of wood particles and metabolize it to acetate and other products that are beneficial for termites (Ohkuma and Kudo, 1996). The protozoan-termite relationship is dependent on synthesizing cellulases produced by the intestinal microflora in termite (Harazono et al., 2003). The function of microflora in termite gut included lignocellulose digestion, acetogenesis, hydrogenesis, methanogenesis, sulfate reduction, and nitrogen fixation (Kudo, 2009). It is widely known that termites cannot survive without intestinal microorganisms and the physiological functions of symbiotic microorganisms in termites are extremely diverse. Earlier, it is proved that oxygen gradients existed in termite guts, and that oxygen is a critical co-substrate for the degradation of lignin and aromatic compounds with the help of aerobic gut microorganisms (Zimmermann, 1990; Brune et al., 1995).

The Formosan subterranean termite Coptotermes formosanus (Isoptera: Rhinotermitidae) are invasive species of "lower termites" from southern China. It has been transported worldwide from its native location to Japan, South Africa, Hawaii, and to the United States in the 20th century. C. formosanus Shiraki is currently regarded as the most destructive, invasive and economically disastrous pest in southern United States and Hawaii (Su and Tamashiro, 1987). Recently, scientists have been involved in developing second generation biofuels using lignocellulosic crops (Sukumaran et al., 2009). The biotechnological challenges in this process involve the breakdown of the highly stable polymers of lignocellulose to simple sugars and redirecting the carbon and electron flow in the metabolic fermentations to biofuels (such as ethanol or hydrogen). The highly efficient lignocellulose degradation ability of symbiotic microorganisms present in the termites might be regarded as a boon for the renewable and alternative fuel industry (Brune, 2007). However, on the pretreatment of lignocellulosic substrates with sulfuric acid, a toxic compound called furfural is produced, which functions as the dominant inhibitory compound for the lignocellulosic hydrolyzates (Belay et al., 1997 and Almeida et al., 2009). It is also known to act as an inhibitor in the fermentation process.

An understanding of intestinal microbes is not enough because majority of the dominant microbes in the gut, such as spirochete-shaped bacteria and protists, cannot be isolated by culture dependent methods (Kudo, 2009). Therefore, the objective of our study was to understand the composition of the microbial flora from termite guts of the termite $C$. formosanus by culture dependent and independent methods and to isolate and screen for microorganisms from the termite gut that could grow in higher concentrations of furfural and lignin. The versatility and function of Bacillus in C. formosanus will also be discussed in this paper.

\section{MATERIALS AND METHODS}

\section{Collection of termites}

Worker termites of $C$. formosanus were collected from dead trees in a forest in Taichung, Taiwan, in June, 2008. The worker termites were separated from the wood surface, surface-sterilized with $70 \%$ alcohol and used for DNA extraction.

\section{Isolation of cultivable bacteria from the termite gut}

Worker termites were surface sterilized with $70 \%$ ethanol and degutted using sterile forceps according to Long et al. (2010). The hind guts were homogenized, and dilution series (up to a dilution of $10^{-12}$ ) were spread-plated on MSM medium at $37{ }^{\circ} \mathrm{C}$ (Chandra et al., 2007). The composition of the MSM medium per liter is as follows: 10 $\mathrm{g}$ Glucose, $5 \mathrm{~g}$ Peptone, $2.4 \mathrm{~g} \mathrm{Na}_{2} \mathrm{HPO}_{4}, 2.0 \mathrm{~g} \mathrm{~K}_{2} \mathrm{HPO}_{4}$, $0.10 \mathrm{~g} \mathrm{NH}_{4} \mathrm{NO}_{3}, 0.010 \mathrm{~g} \mathrm{CaCl}_{2} \cdot 2 \mathrm{H}_{2} \mathrm{O}, 0.250 \mathrm{ml} \mathrm{SL} 1$ stock (240 $\mathrm{mg} \mathrm{H}_{3} \mathrm{BO}_{3}$ / liter of distilled water), $0.050 \mathrm{ml}$ of SL2 stock (160 mg NaMoO $4 \cdot 2 \mathrm{H}_{2} \mathrm{O} /$ liter of distilled water), 0.2 $\mathrm{ml} \mathrm{SL3} \mathrm{stock}\left(200 \mathrm{mg} \mathrm{CuCl} 2 \cdot 2 \mathrm{H}_{2} \mathrm{O}, 700 \mathrm{mg} \mathrm{ZnCl}, 200 \mathrm{mg}\right.$ $\mathrm{NiCl}_{2} \cdot 6 \mathrm{H}_{2} \mathrm{O} /$ liter of distilled water), $0.08 \mathrm{ml} \mathrm{SL} 4$ stock $\left(0.34 \mathrm{ml} 10 \mathrm{~N} \mathrm{HCl}, 250 \mathrm{mg} \mathrm{MnCl}_{2} \cdot 4 \mathrm{H}_{2} \mathrm{O}, 100 \mathrm{mg}\right.$ $\mathrm{CoCl}_{2} \cdot 6 \mathrm{H}_{2} \mathrm{O}$ / liter of distilled water), $1 \mathrm{ml}$ EDTA solution (500 mg / liter of distilled water) and $5 \mathrm{ml} \mathrm{FeSO} \cdot \cdot 7 \mathrm{H}_{2} \mathrm{O}$ solution (220 mg FeSO $4 \cdot 7 \mathrm{H}_{2} \mathrm{O} /$ liter of distilled water).

\section{DNA extraction}

Fifty worker termites were degutted using fine-tipped sterile forceps and their hind guts $(20 \mathrm{mg})$ were excised and suspended in Saline Tris EDTA buffer .The total microbial DNA was extracted using the Easy Tissue and Cell Genomic DNA Purification Kit, (Genemark, USA) according to the manufacturer's instructions.

\section{Denaturing Gradient Gel Electrophoresis (DGGE)}

The concentration and purity of total DNA isolated from the termite gut was measured using a NanoDrop®ND1000 spectrophotometer (NanoDrop Technologies Inc., USA). For the analysis of the bacterial diversity, primer pair EUB968F (5'-CGC CCG GGG CGC GCC CCG GGC GGG GCG GGG GCA CGG GGG GAA CGC GAA GAA CCT TAC-3'; GC clamp is in bold interface) and UNIV1392R (5'-ACG GGC GGT GTG TRC-3') (Nielsen et al., 1999) were used to partially amplify 16S rRNA gene to create a DNA fragment suitable for DGGE analysis. DGGE was performed according to the protocol described by Hayashi et al. (2007) using the Dcode system (BioRad Laboratories, USA). The prominent DGGE bands were excised using a sharp, sterile scalpel under UV illumination and the DNA was extracted from the gel by electroelution using an electroelutor (Genepure ELR9280). Aliquots of the supernatant $(0.5 \mu \mathrm{l})$ were reamplified with the sample PCR mixture using touchdown conditions. The amplicons were purified using the QIAquick (Qiagen) kit, ligated into the "yT and A" cloning vector (Yeastern Biotech Co. Ltd., Taiwan) and transformed into Escherichia coli DH5a by the heat-shock method. The colonies were plated onto Luria-Bertani plates containing ampicillin $\left(50 \mu \mathrm{g} \mathrm{mL}^{-1}\right), 7 \mu \mathrm{L}$ of $20 \%$ 
isopropyl thio- $\beta$-D-galactoside (IPTG) and $40 \mu \mathrm{L}$ of $2 \% \mathrm{X}$ gal by blue and white colony selection (Sambrook and Russell, 2001). The white colonies were selected, and colony PCR was performed using the yeast primers M13 $\mathrm{F}$ and M13 R (Long et al., 2010). The positive transformants were selected for sequencing.

\section{Sequencing and BLAST}

Sequencing of the clones was performed by the Genedragon service (Genedragon, Taiwan) using Seqman (DNAstar, USA). The $16 \mathrm{~S}$ rDNA sequences were compared with the closest sequences deposited in the GenBank (NCBI) public database using the BLASTN software (http://www.ncbi.nlm.nih.gov/BLAST).

\section{Extracellular enzyme activity assay}

The functional properties of the cultured isolates were analyzed for endoglucanase, xylanase, pectinase, amylase, lipase, protease, peroxidase, lignin peroxidase and laccase. The hemicellulase (xylanase) activity was determined by growing the isolates using xylan as the substrate (Chang et al., 2010). The endoglucanase activity was detected by using carboxymethyl cellulose (CMC) as a substrate by using the protocol of Skipper et al. (1985). The isolates were tested for polygalacturonase (pectinase) activity by measuring the degradation of the heteropolysaccharide pectin using a ruthenium red staining solution $(0.05 \%)$ (McKay, 1988). Amylase activity was determined by the protocol of Akpan et al. (1999). Lipase enzyme was qualitatively analyzed using Tributyrin as substrate (Kouker and Jaeger, 1987). The proteolytic activity of the microbes was detected by the skim-milk agar method (Downes and Ito, 2001). The lignin degradation was qualitatively analyzed using syringaldazine solution ( $0.1 \%$ syringaldazine with $95 \%$ ethanol solution) for laccase activity (Ponting, 1999), and the drop-test method was used for lignin peroxidase activity using $0.01 \%$ guaiacol as the substrate (Okino et al., 2000).

\section{Furfural tolerance assay and HPLC}

In order to analyze the furfural tolerance of the bacterial isolates, different concentrations of furfural (Sigma) $(0,15$, 20 and $25 \mathrm{mM}$ ) were added into the MSM culture medium. $1 \%$ of the test bacterium was inoculated and their growth was monitored at different time intervals $(0,12,24$ and 36 hours). The relative growth (\%) was calculated as follows:

Relative growth $(\%)=\left(\mathrm{OD}_{\text {furfural-MSM }} / \mathrm{OD}_{\mathrm{MSM}}\right) \times 100 \%$.

The degradation of furfural was detected quantitatively by HPLC using Agilent 1100. For this experiment, the liquid cultures were centrifuged at $12,000 \mathrm{rpm}$ for 15 minutes and their supernatant collected and analyzed by the protocol of Hyman et al. (2008).

\section{Growth enhancement of bacterial isolates on addition of lignin}

In order to detect if the addition of lignin promoted the growth of the bacterial strains, $1 \%$ of each test bacterium was inoculated into MSM medium containing different concentrations of dealkalized lignin ( $\mathrm{TCl}$, Tokyo Kasei Kougyo) (0, 100, 200, 600 and 1000 ppm). The samples were collected at different time intervals $(0,12,24,36$ hours) and their growth was measured at OD600.The relative growth (\%) is calculated as follows:

Relative growth $(\%)=\left(O D_{L-M S M} / O D_{M S M}\right) \times 100 \%$.

The growth of the lignin tolerant isolates was further tested under anaerobic conditions.

\section{RESULTS}

\section{Bacterial consortia of termite gut from $C$. formosanus} Shiraki

Coptotermes formosanus Shiraki was collected from dead trees in a forest in Taichung, Taiwan. Although previous studies have employed various molecular techniques to detect the bacterial community using 16S rRNA (Husseneder et al., 2005; Shinzato et al., 2005; Kudo, 2009), the bacterial consortia of termite gut from Taiwan has not been analyzed by molecular tools like Denaturing gradient gel electrophoresis (DGGE). Earlier reports have suggested the role of intestinal bacteria, symbiotic protozoa, and endosymbiont of the protist present in the gut of the termite $C$. formosanus for lignocellulosic degradation (Hongoh et al., 2007). Therefore, we have initiated a study to monitor the bacterial consortia in whole hindguts of the termite by $16 \mathrm{~S}$ ribosomal gene targeted DGGE. The DGGE profile revealed that Acinetobacter (band 1-1), Bacteroides thetaiotaomicron (band 1-3), Escherichia coli (band 1-2), and Caulobacter (band 1-4) were the dominant microbes (Figure 1).

\section{Isolation of bacteria and lignin tolerance}

Although recent studies support the direct role of the symbiotic bacteria in the hindgut of the termite in cellulose and xylan hydrolysis, only few reports have focused on the lignin-degrading bacteria. Fourteen different isolates were obtained by using culture dependent methods and were identified using 16S rRNA gene sequencing analysis (Table 1). The cultures were designated as isolate 1-1, isolate $1-2$, isolate $1-3$, isolate $1-5$, isolate $1-8$, isolate 2 1 , isolate $2-2$, isolate 1 , isolate 13 , isolate T4-2, isolate T8-2, isolate T9-3, isolate 27, and isolate T11. Out of these isolates, lignin tolerant organisms were screened using lignin and lignin related aromatic compounds as the carbon source. These bacterial strains isolated from termite gut were inoculated into MSM medium containing different concentrations of lignin. After comparing their growth based on their absorbance at $600 \mathrm{~nm}$, only four bacterial strains belonging to the Genus Bacillus, that is; 
isolate $1-5$, isolate $1-8$, isolate $2-1$, and isolate $2-2$, were enriched by the addition of lignin. Out of the four strains, isolate 1-8 showed maximum growth (Figure 2a) when cultured at higher concentrations of lignin both aerobically and anaerobically. Under aerobic condition, the growth density of isolate 1-8 cultured with 1000 ppm lignin addition was two-folds higher than cultured in MSM medium without lignin (Figure 2b). This result indicated that isolate 1-8 possessed higher lignin utilization under aerobic condition.

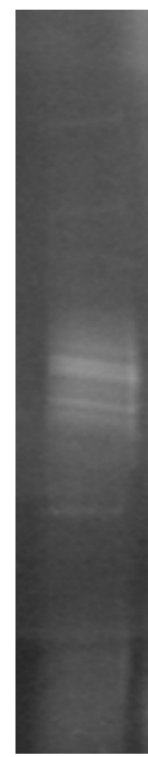

1-1 Acinetobacter sp. $96 \%$

1-2 Escherichia coli $98 \%$

1-3 Bacteroides thetaiotaomicron $89 \%$

1-5 Caulobacter sp. $90 \%$

Figure 1: The 16S rRNA gene profile of gut from $C$. formosanus Shiraki by DGGE analysis.

a)

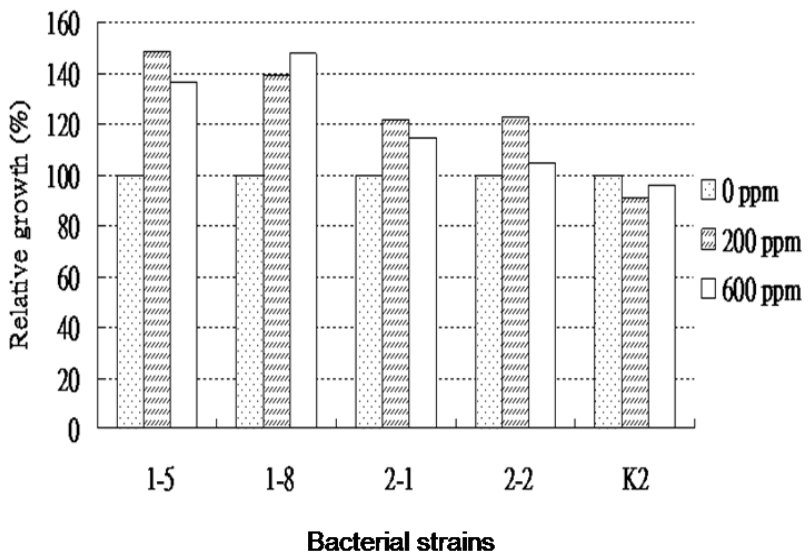

Table 1: Bacterial isolates obtained from the hindgut of Coptotermes formosanus by culture dependent methods.

\begin{tabular}{|c|c|c|c|}
\hline $\begin{array}{l}\text { Isolate } \\
\text { name }\end{array}$ & $\begin{array}{l}\text { Closest } \\
\text { neighbor }\end{array}$ & $\begin{array}{l}\text { Accession } \\
\text { number }\end{array}$ & $\begin{array}{l}\% \\
\text { similarity }\end{array}$ \\
\hline $1-1$ & Bacillus sp & FJ528593.1 & 99 \\
\hline $1-2$ & $\begin{array}{l}\text { Lysinibacillus } \\
\text { fusiformis }\end{array}$ & EU869267.1 & 99 \\
\hline $1-3$ & $\begin{array}{l}\text { Lysinibacillus } \\
\text { fusiformis }\end{array}$ & FJ544400.1 & 99 \\
\hline $1-5$ & Bacillus sp & EU558977.1 & 99 \\
\hline $1-8$ & $\begin{array}{l}\text { Bacillus } \\
\text { cereus }\end{array}$ & FJ644692.1 & 99 \\
\hline $2-1$ & $\begin{array}{l}\text { Bacillus } \\
\text { thuringiensis }\end{array}$ & EU429664.1 & 99 \\
\hline $2-2,1$ & $\begin{array}{l}\text { Bacillus } \\
\text { thuringiensis }\end{array}$ & EU429660.1 & 99 \\
\hline 13 & $\begin{array}{l}\text { Bacillus } \\
\text { thuringiensis }\end{array}$ & AM778997.1 & 99 \\
\hline T4-2 & $\begin{array}{l}\text { Citrobacter } \\
\text { farmeri }\end{array}$ & AF025370.1 & 99 \\
\hline T8-2 & $\begin{array}{l}\text { Citrobacter } \\
\text { farmeri }\end{array}$ & AF025370.1 & 100 \\
\hline T9-3 & $\begin{array}{l}\text { Citrobacter } \\
\text { amalonaticus }\end{array}$ & AF025371.1 & 99 \\
\hline 27 & $\begin{array}{l}\text { Enterococcus } \\
\text { avium }\end{array}$ & EU391533.1 & 99 \\
\hline 11 & $\begin{array}{l}\text { Enterococcus } \\
\text { avium }\end{array}$ & JF947348.1 & 99 \\
\hline
\end{tabular}

b)

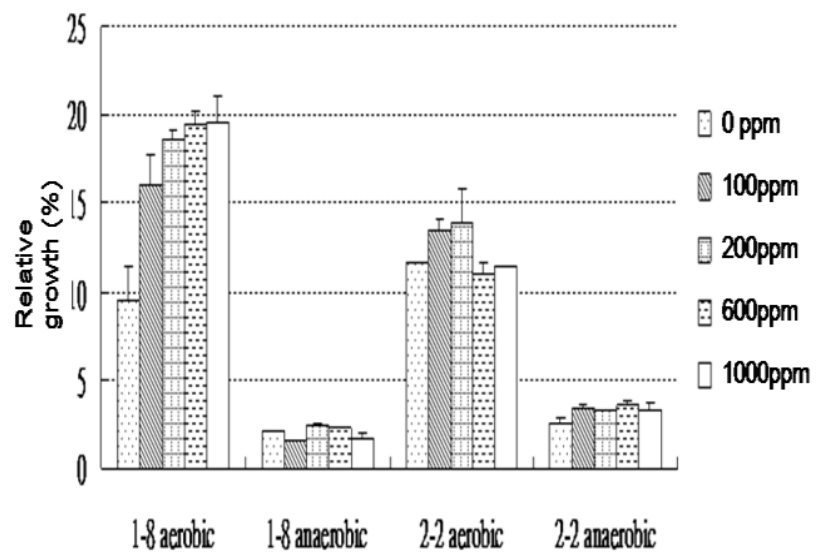

Figure 2: The relative growth analysis of bacterial isolates in MSM medium containing different concentrations of lignin. a) Relative growth (\%) of isolates 1-5, 1-8, 2-1 and 2-2 in different concentrations of lignin (200ppm and $600 \mathrm{ppm}$ ). K2 Bacillus thermoamylovorans was used as the control strain. b) Relative growth (\%) of isolate 1-8 and 2-2 in higher concentrations of lignin (1000 ppm) under aerobic and anaerobic conditions. 
Table 2: Qualitative enzyme profiles of the bacterial isolates obtained from the hind gut of Coptotermes formosanus.

\begin{tabular}{|c|c|c|c|c|c|c|c|c|c|c|c|c|}
\hline \multirow{2}{*}{ Enzyme } & \multirow{2}{*}{ Substrate } & \multirow{2}{*}{ Condition } & \multicolumn{10}{|c|}{ Strains } \\
\hline & & & 1 & 13 & 27 & $1-5$ & $1-8$ & $2-1$ & $2-2$ & T8-2 & $\mathrm{K} 2$ & DH5a \\
\hline \multirow[t]{2}{*}{ Protease } & Skim milk & Aerobic & + & + & - & + & + & + & + & - & + & - \\
\hline & & Anaerobic & + & + & + & + & + & + & + & - & + & - \\
\hline \multirow[t]{2}{*}{ Xylanase } & Xylan & Aerobic & - & - & - & - & - & - & - & - & + & - \\
\hline & & Anaerobic & - & - & - & - & - & - & - & - & + & - \\
\hline \multirow[t]{2}{*}{ Lipase } & Tributyrin & Aerobic & + & + & - & + & + & + & + & - & + & - \\
\hline & & Anaerobic & + & + & - & + & + & + & + & - & + & - \\
\hline \multirow[t]{2}{*}{ Endoglucanase } & CMC & Aerobic & - & - & - & + & + & - & + & - & + & - \\
\hline & & Anaerobic & - & - & - & + & + & - & + & - & + & - \\
\hline \multirow[t]{2}{*}{ Pectinase } & Pectin & Aerobic & - & - & - & - & - & - & - & - & + & - \\
\hline & & Anaerobic & - & - & - & - & - & - & - & - & + & - \\
\hline \multirow[t]{2}{*}{ Amylase } & Starch & Aerobic & + & + & - & + & + & + & + & - & + & - \\
\hline & & Anaerobic & + & + & - & + & + & + & + & - & + & - \\
\hline
\end{tabular}

Isolate 1, 13, 27, 1-5, 1-8, 2-1, 2-2, T8-2 were the tested for their enzymatic activities. K2- Bacillus thermoamylovorans as the positive control strain and DH5 a was used as a negative control strain. "+" indicates positive activity and "-" indicates no enzyme activity.

Table 3: Lignin degradation related peroxidase, lignin peroxidase and laccase profiles from the bacterial isolates.

\begin{tabular}{|c|c|c|c|c|c|c|c|c|c|c|}
\hline Enzyme & Time (days) & Irpex lacteus & 1 & 13 & 27 & $1-5$ & $1-8$ & $2-1$ & $2-2$ & T8-2 \\
\hline Peroxidase & 4 & + & + & + & + & + & + & + & + & + \\
\hline Lignin peroxidase & 14 & + & + & + & + & + & + & + & + & + \\
\hline Laccase & 15 & + & - & - & - & - & - & - & - & - \\
\hline
\end{tabular}

Isolate $1,13,27,1-5,1-8,2-1,2-2$, T8-2 were the tested for their enzymatic activities. Irpex lacteus was used as the positive control strain."+" indicates positive activity and "-" indicates no enzyme activity.

\section{Qualitative enzyme assays}

In this experiment, the extracellular enzymatic profiles of the isolates from the termite hindguts were qualitatively analyzed for protease, xylanase, lipase, endoglucanase and amylase (Table 2). The ligninolytic activity was assessed qualitatively by culturing the isolates on a petriplate containing lignin (100 ppm) and their peroxidase, lignin peroxidase and laccase were monitored (Table 3). The fungal strain Irpex lacteus was used as the positive control. The results indicated that all the isolates from the hindguts of $C$. formosanus exhibited protease, lipase, amylase, peroxidase and lignin peroxidase activity (Table 2 and 3). Only three lignin tolerant strains, isolate $1-5$, isolate $1-8$, and isolate $2-2$, possessed endoglucanase activity (Table 2)

\section{Furfural tolerance assay}

In the process of lignocellulosic pretreatment, lignin-borne toxic compounds like furfural were produced and they served as a potent inhibitor of microbial growth and metabolism (Klinke et al., 2002; Ingram et al., 1999). Therefore, the following experiment was designed to analyze the ability of the bacterial isolates to grow at a higher concentration of furfural as well as degrade them to less toxic compounds. Different concentrations of furfural were inoculated with the isolates for the toxin tolerance assay and their relative growth result showed that Bacillus isolates 1-8 and 2-2 was resistant to $20 \mathrm{mM}$ furfural with $60 \%$ relative growth in the MSM medium at $37^{\circ} \mathrm{C}$ for 24 hours. It was observed that isolate 1-8 showed higher tolerance than isolate $2-2$ at $25 \mathrm{mM}$ furfural concentration with $40 \%$ relative growth (Figure 3a). The furfural degrading ability was quantitatively measured by HPLC assay at $37^{\circ} \mathrm{C}$ for $24 \mathrm{hrs}$. The result indicated that both the strains could degrade $98 \%$ of furfural at a lower concentration of $15 \mathrm{mM}$ (Figure $3 \mathrm{~b}$ ). When the furfural concentration was raised to $20 \mathrm{mM}$, isolate $2-2$ retained the higher degrading ability $(97 \%)$ than isolate $1-8(38 \%)$. Both of the strains could not degrade furfural at a higher furfural concentration of $25 \mathrm{mM}$ (Figure $3 \mathrm{~b}$ ).

\section{DISCUSSION}

Termites harbored a complex microbial community in their intestines and they contributed a crucial role in the digestion of lignocellulose, as well as in the global carbon recycling. As only $1 \%$ of the gut microbes were cultivable by traditional cultivation methods, it was necessary to identify the uncultivable microbes by culture independent methods like DGGE. By DGGE-16S rDNA sequencing, 
(a)

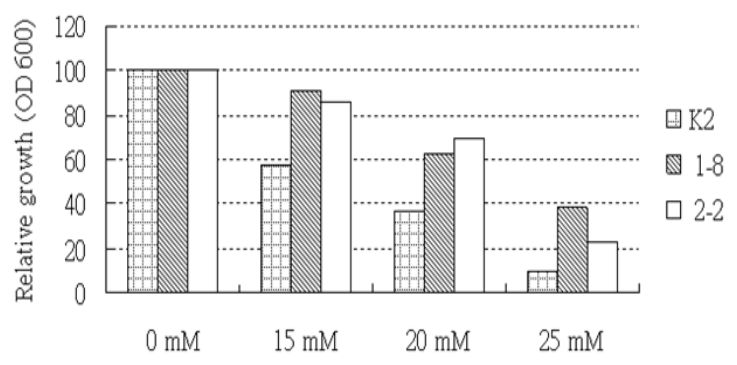

Furfural concentration

(b)

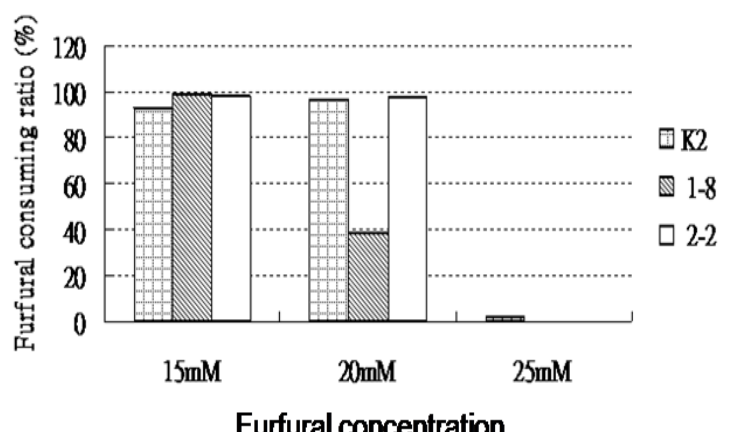

Figure 3: Furfural tolerance test and degradation. a) Bacillus isolates K2, 1-8 and 2-2 grown in MSM medium containing different concentrations furfural. K2 Bacillus thermoamylovorans was used as a control strain b) Furfural consuming assay

majority of the prokaryotes belonging to the Genus Acinetobacter, Bacteriodes, Escherichia and Caulobacter were identified; whereas Lysinobacillus fusiformis, $B$. cereus, B. thuringiensis, Enterococcus avium (Phylum Firmicutes) and Citrobacter (Phylum Proteobacteria) were isolated by culture dependent methods. From our study and previous studies, Phylum Firmicutes showed greater species diversity and were suggested to be involved in acetogenesis, sugar degradation and fermentation (Kudo, 2009; Noda et al., 2009). Earlier reports have suggested that most of the dominant microbes in gut of $C$. formosanus belonged to the Phylum Bacteriodetes and constituted $70-80 \%$ of total intestinal bacterial cells in their microbial flora (Noda et al., 2003; Hongoh et al., 2007).They were discovered as an endosymbiont of the host protist Pseudotrichonympha grassii in the gut of the termite $C$. formosanus by fluorescence in situ hybridization (FISH) analysis, transmission electron microscopy and PCR-amplified molecular analyses (Brune and Ohkuma, 2011). They were also suggested to help in the fermentation of sugars, nitrogenous compounds and cellulose digestion as well as in uric acid degradation (Husseneder, 2010). Acinetobacter sp. have been detected as a minor group in gut of Coptotermes formosanus from USA (Husseneder et al., 2005). Thus, it is suggested that interdependency existed between the hosts and the symbionts and that vertical transmission was a way of acquiring these symbionts (Husseneder, 2010). Co-evolution led to the continuity of these symbionts in the termite gut for several generations (Noda et al., 2009).

Some studies have reported that Acinetobacter, Bacteroides, and Bacillus existed in the intestine of termites and other invertebrates and were involved in the first stage of cellulose and hemicellulose hydrolysis (König et al., 2005; König, 2006). Moreover, the genus Bacillus, Escherichia, Enterococcus, and Citrobacter belonged to the intermediate stage of microorganisms, involved in oxidation and fermentation of cellulose and hemicellulosic substrates (König et al., 2005). In comparison with the rumen system that contained strict anaerobic cellulolytic bacteria such as the genera Ruminococcus and Clostridium, the termite gut harbored facultatively anaerobic or micro-aerophilic bacteria (Chang et al., 2010). This phenomenon might be due to the microbial proportion of the termite gut and the smaller intake of food than the rumen, which caused the larger oxygen influx in termite's gut system (Brune, 1998). A pronounced spatial differentiation in oxidation-reduction gradient that supplied with oxygen via the epithelium has been studied earlier (Brune and Kühl, 1996); Noirot, 1995). Thus, the microbial composition of the gut of $C$. formosanus was believed to be influenced by the above physiological factors.

After the pretreatment process of lignocellulolytic substrates with sulfuric acid, higher concentration of furfural was produced. The amount of furfural varied for different lignocellulolytic crops. After the pretreatment process, there was a washing step involved to remove excess of furfural. Only lower quantities of furfural approximately (5-10 mM) would be present on the pretreated substrates. Apparently, this concentration was found to be inhibitory to the bacteria used in fermentation process for biofuel production. Earlier reports have showed that cultures were severely inhibited at a concentration of $25 \mathrm{mM}$ furfural. Some methanogens were anaerobically able to transform furfural $(10 \mathrm{mM})$ to furfuryl alcohol (Belay et al., 1997). Therefore, $25 \mathrm{mM}$ of furfural was chosen as the maximum concentration for studying the furfural tolerance. Studies have shown that furfural waste could be treated by anaerobic digestion with mixed bacterial consortia (Brune et al., 1982). Since Bacillus isolates 1-8 and 2-2 could grow aerobically as well as anaerobically, they could possibly be mixed as a coculture with sulfate reducing bacteria that could metabolize furfuryl alcohol to acetic acid (Boopathy and Daniels, 1991) and acetate- utilizing methanogens which could convert acetate to methane and carbon dioxide. They could also probably be co-cultured with ethanologenic bacteria and encounter the limitations caused by furfural in fermentation process (Mills et al., 2009).

Aromatic compounds and biphenyl moieties were expected to be abundantly present in the hindgut of termites (Brune et al., 1995). In fact, several bacteria have been isolated and screened from $C$ formosanus, and they possessed the ability to degrade chlorinated aromatic compounds, phenylalkanoic acids (breakdown products of 
lignin), phenol, and steroids (Harazono et al., 2003, Hayashi et al., 2007). In this study, we have also analyzed and isolated the microflora from $C$. formosanus guts which possess ligninolytic enzymes that could possible help in the degradation of lignin. By enrichment techniques, the lignin tolerant bacterial consortia from termite hindgut was isolated and identified as Bacillus isolates 1-8 and 2-2. Our studies helped in screening lignin and furfural tolerant isolates and analyzing the lignocellulolytic enzymes qualitatively. HPLC studies are yet to be done quantitatively in order to understand the lignocellulosic degradation process in detail. Earlier Citrobacter sp. have been isolated and characterized to be aromatic degrading microorganisms (Harazono et al., 2003). Citrobacter sp. isolate T8-2, was also detected to contain lignin degrading enzymes but they were not found to be tolerant to furfural (data not shown). These results indicated that these microbes might cumulatively play a role in the digestion of polysaccharides and aromatic compounds in the gut of $C$. formosanus.

Bacillus sp. also were discussed as the contributors in early and intermediate steps of polymer degradation under oxygen limitation in other intestinal systems of termites and lower invertebrates such as springtails, earthworms, isopods and millipedes (König, 2006). Other Bacillus species like Lysinibacillus fusiformis, Bacillus cereus and soil bacterium like Bacillus thuringienesis were also isolated in our study and probably could function in polymer degradation. Interestingly, $B$. thuringiensis is known as an effective bio-insecticidal bacterium for the control of pests such as Lepidoptera, Diptera, and Coleoptera, and could produce parasporal crystals with different morphology and insecticidal activity via its spore formation (Crickmore, 2006; Roh et al., 2007). Furthermore, $B$. cereus and $B$. thuringiensis strains harbored the gene cluster encoding acyl homoserine lactone $(\mathrm{AHL})$ lactonases and zwittermicin $A$ which could inhibit the growth of some gram-negative bacteria, Oomycetes and many plant pathogenic fung (Handelsman et al., 1990; Dong et al., 2000). This could be the reason why the gut microflora in termite could compete with allochthonous microbes by insecticidal activity in natural ecosystems for maintaining the existing gut microflora. Some studies have reported that Bacillus widely enhances the germination of spores in earthworms and were also important phosphorus-solubilizing microorganisms, resulting in improved plant growth (Beneduzi et al., 2008). These findings widen the target range of Bacillus in termites besides insecticidal activity for suppressing plant pathogens and growth promotion in plants. The $C$. formosanus termites, which were invasive and difficult to control destructive pests in subtropical and tropical, might also be beneficial to kill other insects which were harmful to plants by possibly releasing the BT spores from their termite gut into the environment by defecation and via other termites by coprophagy and trophallaxis (Zhang et al ., 2003; Husseneder, 2010). Therefore from these studies and previous reports, we can prove that the termite gut of Coptotermes formosanus acts as a reservoir of various beneficial bacteria which could probably be useful for various industrial processes (Brune, 1998 and Hayashi et al., 2007).

\section{CONCLUSION}

To conclude, the Bacillus isolates 1-8 and 2-2 cultured from $C$. formosanus guts, possessed the peroxidase, lignin peroxidase, protease, and endoglucanase enzymes and could grow in a medium containing lignin as the sole source of carbon. The tolerance assay of furfural indicated that both the strains could tolerate higher concentrations of furfural and could also degrade furfural to lesser toxic compounds. Co-culture studies with these isolates and fermentative bacteria will be done in the future with respect to study their contribution in bio-fuel production.

\section{ACKNOWLEDGEMENT}

The authors wish to acknowledge Mr. Chun-I Chu, Department of Entomology, for field sampling and identification of the termites.

\section{REFERENCES}

Akpan, I., Bankole, M. O. and Adesemowo, A. W. (1999). A rapid plate culture method for screening of amylase producing microorganisms. Biotechnology techniques 13(6), 411-413.

Almeida, J. R. M., Bertilsson, M., Gorwa-Grauslund. M. F., Gorsich, S. and Lidén, G. (2009). Metabolic effects of furaldehydes and impacts on biotechnological processes. Applied Microbiology and Biotechnology 82, 625-638.

Belay, N., Boopathy, R. and Voskuilen, G. (1997). Anaerobic transformation of furfural by Methanococcus deltae (delta) LH. Applied and Environmental Microbiology 63(5), 2092-2094.

Beneduzi, A., Peres, D., Beschoren da Costa, P., Zanettini, M. H. B. and Passaglia, L. M. P. (2008). Genetic and phenotypic diversity of plant-growthpromoting Bacilli isolated from wheat fields in southern Brazil. Research in Microbiology 159(4), 244-250.

Bhat, M. K. and Bhat, S. (1997). Cellulose degrading enzymes and their potential industrial applications. Biotechnology advances 15(3-4), 583-620.

Boopathy, R. and Daniels, L. (1991). Isolation and characterization of a furfural degrading sulfate reducing bacterium from an anerobic digestor. Current Microbiology 23, 327-332.

Brune, A. (1998). Termite guts: the world's smallest bioreactors. Trends in Biotechnology 16(1), 16-21.

Brune, A. (2007). Microbiology: woodworker's digest. Nature 450, 487-488.

Brune, A. and Kühl, M. (1996). pH profiles of extremely alkaline hindguts of soil-feeding termites (Isoptera: Termitidae) determined with microelectrodes. Journal of Insect Physiology 42, 1121-1127.

Brune, A., Miambi, E. and Breznak, J. A. (1995). Roles of oxygen and the intestinal microflora in the 
metabolism of lignin-derived phenylpropanoids and other monoaromatic compounds by termites. Applied and Environmental Microbiology 61(7), 2688-2695.

Brune, A. and Ohkuma, M. (2011). Role of termite gut microbiota in symbiotic digestion. In: Bignell, D. E., Roisin, Y. and Lo, N. (eds.). Biology of Termites: A Modern Synthesis. Springer-Verlag, Berlin. pp. 439475.

Brune, G., Schoberth, S. M. and Sahm, H. (1982). Anaerobic treatment of an industrial wastewater containing acetic acid, furfural and sulphite. Process Biochemistry 17, 20-35.

Chabannes, M., Ruel, K., Yoshinaga, A., Chabbert, B., Jauneau, A., Joseleau, J. P. and Boudet, A. M. (2001). In situ analysis of lignins in transgenic tobacco reveals a differential impact of individual transformations on the spatial patterns of lignin deposition at the cellular and subcellular levels. Plant Journal 28, 271-282.

Chandra, R., Raj, A., Purohit, H. J. and Kapley, A. (2007). Characterisation and optimization of three potential aerobic bacterial strains for kraft lignin degradation from pulp paper waste. Chemosphere 67(4), 839-846.

Chang, J-J., Lin, J-J., Ho, C-Y., Chin, W-C. and Huang, C-C. (2010). Establishment of rumen-mimic bacterial consortia: A functional union for bio-hydrogen production from cellulosic bioresource. International Journal of Hydrogen Energy 35, 13399-13406.

Crickmore, N. (2006). Beyond the spore-past and future developments of Bacillus thuringiensis as a biopesticide. Journal of Applied Microbiology 101, 616-619.

Dong, Y-H., Xu, J-L., Li, X-Z. and Zhang, L-H. (2000). AiiA, an enzyme that inactivates the acylhomoserine lactone quorum-sensing signal and attenuates the virulence of Erwinia carotovora. Proceedings of the National Academy of Sciences of the United States of America 97(7), 3526-3531.

Downes, F. P. and Ito, K. (2001). Compendium of Methods for the Microbiological Examination of Foods, $4^{\text {th }}$ edition. American Public Health Association, Washington, DC.

Handelsman, J., Raffel, S., Mester, E. H., Wunderlich, L. and Grau, C. R. (1990). Biological control of damping-off of alfalfa seedlings with Bacillus cereus UW85. Applied and Environmental Microbiology 56, 713-718.

Harazono, K., Yamashita, N., Shinzato, N., Watanabe, Y., Fukatsui, T. and Kurane, R. (2003). Isolation and characterization of aromatics-degrading microorganisms from the gut of the lower termite Coptotermes formosanus. Bioscience, Biotechnology, and Biochemistry 67(4), 889-892.

Hayashi, A., Aoyagi, H., Yoshimura, T. and Tanaka, H. (2007). Development of a novel method for screening microorganisms using symbiotic associations between insect (Coptotermes formosanus Shiraki) and intestinal microorganisms. Journal of Bioscience and Bioengineering 103(4), 358-367.
Hongoh, Y., Sato, T., Noda, S., Ui, S., Kudo, T. and Ohkuma, M. (2007). Candidatus Symbiothrix dinenymphae: bristle-like Bacteroidales ectosymbionts of termite gut protists. Environmental Microbiology 9(10), 2631-2635.

Husseneder, C. (2010). Symbiosis in subterranean termites: A review of insights from molecular studies. Termite symbiosis 39(2), 378-388.

Husseneder, C., Wise, B. R. and Higashiguchi, D. T. (2005). Microbial diversity in the termite gut: A complementary approach combining culture and culture-independent techniques. In: Lee, C-Y and Robinson, W. H. (eds.). Proceedings of $5^{\text {th }}$ International Conference on Urban Pests, 10-13 July 2005, Singapore. P\&Y Design Network, Penang, Malaysia. pp 189-195.

Hyman, D. and National Renewable Energy Laboratory (2008). Determination of acid soluble lignin concentration curve by UV-Vis spectroscopy (electronic resource). Laboratory analytical procedure $(L A P)$. National Renewable Energy Laboratory, Golden, Colorado.

Ingram, L. O., Aldrich, H. C., Borges, A. C., Causey, T. B., Martinez, A., Morales, F., Saleh, A., Underwood, S. A., Yomano, L. P., York, S. W., Zaldivar, J. and Zhou, S. (1999). Enteric bacterial catalysts for fuel ethanol production. Biotechnology progress 15, 855-866.

Klinke, H. B., Ahring, B. K., Schmidt, A. S. and Thomsen, A. B. (2002). Characterization of degradation products from alkaline wet oxidation of wheat straw. Bioresource Technology 82(1), 15-26.

König, H. (2006) Bacillus species in the intestine of termites and other soil invertebrates. Journal of Applied Microbiology 101(3), 620-627.

König, H., Fröhlich, J. and Hertel, H. (2005). Diversity and lignocellulolytic activities of cultured microorganisms. In: König, H. and Varma, A. (eds.). Intestinal Microorganisms of Termites and Other Invertebrates. Springer-Verlag, Berlin. pp. 272-302.

Kouker, G. and Jaeger, K-E. (1987). Specific and sensitive plate assay for bacterial lipases. Applied and Environmental Microbiology 53(1), 211-213.

Kudo, T. (2009). Termite-microbe symbiotic system and its efficient degradation of lignocellulose Bioscience, Biotechnology and Biochemistry 73(12), 2561-2567.

Long, Y. H., Xie, L., Liu, N., Yan, X., Li, M. H., Fan, M.Z. and Wang, Q. (2010). Comparison of gut-associated and nest associated microbial communities of a fungus-growing termite (Odontotermes yunnanensis). Insect Science 17(3), 265-276.

McKay, A. M. (1988). A plate assay method for the detection of fungal polygalacturonase secretion. FEMS Microbiology letters 56(3), 355-358.

Mills, T. Y., Sandoval, N. R. and Gills, R. T. (2009). Cellulosic hydrolysate toxicity and tolerance mechanisms in E. coli. Biotechnology for Biofuels 2, 26.

Nielsen, A. T., Liu, W-T, Filipe, C., Grady, L. Jr., Molin, S. and Stahl D. A. (1999). Identification of a novel 
group of bacteria in sludge from a deteriorated biological phosphorus removal reactor. Applied and Environmental Microbiology 65(3), 1251-1258.

Noda, S., Hongoh, Y., Sato, T. and Ohkuma, M. (2009). Complex coevolutionary history of symbiotic Bacteroidales bacteria of various protists in the gut of termites. BMC Evolutionary Biology 9(1), 158.

Noda, S., Ohkuma, M., Yamada, A., Hongoh, Y. and Kudo, T. (2003). Phylogenetic position and in situ identification of ectosymbiotic spirochetes on protists in the termite gut. Applied and Environmental Microbiology 69(1), 625-633.

Noirot, C. (1995). The gut of termites (Isoptera). Comparative anatomy, systematics, phylogeny. I. Lower termites. Annales de la Societe Entomologique de France 31, 197-226.

Ohkuma, M. and Kudo, T. (1996). Phylogenetic diversity of the intestinal bacterial community in the termite Reticulitermes speratus. Applied and Environmental Microbiology 62(2), 461-468.

Okino, L. K., Machado, K. M. G., Fabris, C. and Bonon, V. L. R. (2000). Ligninolytic activity of tropical rainforest basidiomycetes. World Journal of Microbiology and Biotechnology 16, 889-893.

Pérez, J., Muñoz-Dorado, J., de la Rubia, T. and Martínez, J. (2002). Biodegradation and biological treatments of cellulose, hemicellulose and lignin: an overview. International Microbiology 5(2), 53-63.

Ponting, S. B. (1999). Qualitative methods for the determination of lignocellulolytic enzyme production by tropical fungi. Fungal diversity 2, 17-33.

Roh, J. Y., Choi, J. Y., Li, M. S., Jin, B. R. and Je, Y. H. (2007). Bacillus thuringiensis as a specific, safe, and effective tool for insect pest control. Journal of Microbiology and Biotechnology 17(4), 547-559.

Sambrook, J. and Russell, D. W. (2001). Screening bacterial colonies using X-gal and IPTG: $\alpha$ complementation. In: Argentine, J., Irwin, N., Janssen, K. A., Curtis, S. and Zierler, M. (eds). Molecular Cloning. Cold Spring Harbor Laboratory Press, Spring Harbor, NewYork. Vol. 1, pp.1.1231.125 .

Shinzato, N., Muramatsu, M., Matsui, T. and Watanabe, Y. (2005). Molecular phylogenetic diversity of the bacterial community in the gut of the termite Coptotermes formosanus. Bioscience Biotechnology and Biochemistry 69(6), 1145-1155.

Skipper, N., Sutherland, N. M., Davies, R. M., Kilburn, D., Miller, R., Warren, A. and Wong, R. (1985). Secretion of a bacterial cellulase by yeast. Science 230(4728), 958-960.

Su, N-Y and Tamashiro, M. (1987). An overview of the Formosan subterranean termite (Isoptera: Rhinotermitidae) in the world. In: Tamashiro, M. and $\mathrm{Su}$, N.Y., (eds.). Biology and Control of the Formosan Subterranean Termite. Univ. of Hawaii, Honolulu. pp. 3-15.

Sukumaran, R. K., Singhania, R. R., Mathew, G. M. and Pandey, A. (2009). Cellulase production using biomass feedstock and its application in lignocellulosic saccharification for ethanol production. Renewable energy 34, 421-424.

Tokuda, G., Yamaoka, I. and Noda, H. (2000). Localization of symbiotic clostridia in the mixed segment of the termite Nasutitermes takasagoensis (Shiraki). Applied and Environmental Microbiology 66(5), 2199-2207.

Zhang, J. H., Wang, W. L., Li, W. J., Zhuang,T. Y. and Chen, L. L. (2003). Analysis on the trophollaxis of Coptotermes formosanus Shiraki. Journal of Central Chin Normal University (Natural Sciences) 37, 90-92.

Zimmermann, W. (1990). Degradation of lignin by bacteria. Journal of Biotechnology 13, 119-130. 